\title{
Effects of Salt Stress on the Enzyme Activity and Chlorophyll Content of Bush Cinquefoil (Potentilla fruticosa L.)
}

\author{
Hang LIU, Tian MA, Cheng-xia ZHANG*, Qun XIA, Tao JU, Ju-xiang DU, Ji-ping YUAN \\ Jiangsu Agri-animal Husbandry Vocational College, Taizhou, China \\ *Ph. D. Cheng-xia ZHANG, associate professor, engaged in garden ornamental and plants research.
}

\author{
*Corresponding Author: Cheng-xia ZHANG, Ph. D. Cheng-xia ZHANG, associate professor, engaged \\ in garden ornamental and medicinal plants research.
}

\begin{abstract}
In order to studied the effect of salt stress onantioxidant enzyme system and photosynthetic pigments in the leaves of Bush Cinquefoil (Potentilla fruticosa L.), and the correlation between the important physiological characteristics of salt tolerance. Bush Cinquefoil (Potentilla fruticosa L.) cutting seedlings was selected as the material, through watering $\mathrm{NaCl}$ and $\mathrm{Na}_{2} \mathrm{SO}_{4}$ solution of different concentration. The results showed that: with the constant enhancement of salt stress, SOD activity, chlorophyll content of Potentilla fruticosa L. leaves decreased; POD activity showed a rising trend; the carotenoid content decreased; the chlorophyll content of leaves was positive correlation with SOD, negatively correlated with POD, so SOD had certain protective effect on chlorophyll. Based on the analysis, Potentilla fruticosa L. has a certain tolerance to salt, suitable for planting in areas with low degree of salinization.
\end{abstract}

Keywords: salt stress; Potentilla fruticosa L.; antioxidant enzyme system; photosynthetic pigments

\section{INTRODUCTION}

Bush Cinquefoil (Potentilla fruticosa L.) also known as Prunus humilis, is a deciduous shrub of Potentilla of Rosaceae. Dense branches and leaves, yellow flowers, shaped like plum blossoms, flowering from June to July, suitable for garden ornamental shrubs or hedgerows [1]. Leaves and fruits contain tannin, which can be used to extract tannin extract. Tender leaves can be drunk on behalf of tea leaves. Flowers and leaves are used as medicines and have the effects of invigorating spleen, eliminating dampness, clearing summer heat, and regulating menstruation [2]. Bush Cinquefoil (Potentilla fruticosa L.), resistant to low temperatures of $-50{ }^{\circ} \mathrm{C}$ and likes moist soil with good drainage. it is resistant to drought and barren. Bush Cinquefoil is an excellent greenery and medicinal plant, which has broad application prospect. However, the research and promotion of Bush Cinquefoil is still in its primary stage, mainly focusing on medicinal and reproductive aspects, while the research on salt resistance of Bush Cinquefoil is relatively few, and mainly under $\mathrm{NaCl}$ stress. Chloride and sulfate are the main salt damage components in the saline-alkali land in the arid region of northern China, which severely restricts the economic development in the arid region of northern China [3]. In order to expand the application of Bush Cinquefoil in saline-alkali regions in north China, especially in arid regions in north China, this project studied the effects of different concentrations of $\mathrm{NaCl}$ and $\mathrm{Na}_{2} \mathrm{SO}_{4}$ solution treatment on antioxidant enzyme system and chlorophyll content of Bush Cinquefoil (Potentilla fruticosa L.) seedlings, in order to provide reference for improving the salt tolerance of Bush Cinquefoil and its application scope in north China.

\section{MATERIALS AND METHODS}

\subsection{Materials}

The seedlings tested were 2 - year - old Bush Cinquefoil cuttage seedlings. seedlings with the same growth and strong plants were selected from the nursery of Hebei agricultural university to be planted in a ceramic basin with a diameter of $21 \mathrm{~cm}$ and a depth of $25 \mathrm{~cm}$. the cultivation medium was mainly ordinary garden soil in. During the period of normal management, experiment. was carried out when the young plant of Bush Cinquefoil was about $50 \mathrm{~cm}$ tall. 10 plants in each group and 30 plants in each treatment set up 3 repeated. $0.2 \%, 0.4 \%, 0.6 \%, 0.8 \%$ and $1.0 \% \mathrm{NaCl}$ and $\mathrm{Na}_{2} \mathrm{SO}_{4}$ solutions were respectively applied into the basin in 11 three times to ensure sufficient salt absorption, and distilled water was used as the control (CK). 
The test materials of Bush Cinquefoil were planted in a ceramic flowerpot with a diameter of $21 \mathrm{~cm}$ and a depth of $25 \mathrm{~cm}$. the cultivation medium was mainly., a common garden soil. Every 10 pots are one group, and every 30 pots are treated, i.e. 3 repeated. Pour clear water into flowerpots as control (CK), and place trays at the bottom of flowerpots to prevent salt loss from.

\subsection{Test Methods and Determination Methods}

After 7 and 13 days of $\mathrm{NaCl}$ and $\mathrm{Na}_{2} \mathrm{SO}_{4}$ stress, 20 mature leaves were randomly taken from plants at the same stress level between 7: 00 and 8: 00 in the morning to measure the physiological indexes of salt tolerance. The determination of chlorophyll content is based on the method of the Bo chin[4], the determination of superoxide dismutase (SOD) activity is based on azoblue tetrazole photochemical reduction method[3], and the determination of peroxidase (POD) activity is based on guaiacol method [5]

The test data were analyzed by SPSS 19.0 statistical software for variance and correlation between indicators and excel 2007 was used to tabulate.

\section{RESULTS AND ANALYSIS}

\subsection{Effect of Salt Stress on Antioxidant Enzyme System of Bush Cinquefoil}

As can be seen from table 1, under salt stress, SOD activity in leaves of Bush Cinquefoil decreased with the increase of salt concentration in. Except for $\mathrm{NaCl}$ stress of $0.2 \%$ salt concentration for 7 days, SOD activity had no significant difference with CK, and SOD activity of other treatment levels had significant difference with CK. After 13 days of stress, all treatments with different concentrations of $\mathrm{NaCl}$ reached significantly different levels of. After 7 days and 13 days of $\mathrm{Na}_{2} \mathrm{SO}_{4}$ stress, the treatment with different concentrations reached significant difference level with $\mathrm{CK}$, and after 13 days of stress, there was significant difference between the treatment concentrations of. In comparison, SOD activity under $\mathrm{NaCl}$ stress was lower than that under $\mathrm{Na}_{2} \mathrm{SO}_{4}$ stress, which indicated that $\mathrm{SOD}$ activity in leaves of Bush Cinquefoil was more sensitive to $\mathrm{Na}_{2} \mathrm{SO}_{4}$ stress in.

With the increase of $\mathrm{NaCl}$ and $\mathrm{Na}_{2} \mathrm{SO}_{4}$ stress levels, pod activity in leaves of Bush Cinquefoil showed an overall upward trend, and the values were higher than CK. After 7 days of stress, POD activity and $\mathrm{CK}$ in leaves treated with $0.8 \%$ and $1.0 \% \mathrm{NaCl}$ reached significantly different levels of. After 13 days of stress, all treatments with different $\mathrm{NaCl}$ concentrations reached significantly different levels of. from CK except for $\mathrm{Na}_{2} \mathrm{SO}_{4}$ stress of $0.2 \%$ salt concentration for 7 days, SOD activity had no significant difference with $\mathrm{CK}$, and SOD activity at other treatment levels had significant difference with CK. After 13 days of $\mathrm{Na}_{2} \mathrm{SO}_{4}$ stress, there were significant differences between different treatments.

In comparison, under the same treatment time and salt concentration stress, the SOD activity and pod activity of $\mathrm{NaCl}$ treatment were lower than that of $\mathrm{Na}_{2} \mathrm{SO}_{4}$ treatment, which indicated that the effect of $\mathrm{NaCl}$ stress on antioxidant enzyme system of Bush Cinquefoil was stronger than that of $\mathrm{Na}_{2} \mathrm{SO}_{4}$ stress on.

Table1. The effect of salt stress on SOD enzyme activities, POD enzyme activities of Potentilla fruticosa $L$. leaves

\begin{tabular}{|c|c|c|c|c|c|}
\hline & \multirow{3}{*}{$\begin{array}{c}\% \\
\text { Salt } \\
\text { Concentration }\end{array}$} & \multicolumn{4}{|c|}{ Days of treatment $(\mathrm{d})$} \\
\hline & & \multicolumn{4}{|c|}{$\mathrm{NaCl} \quad \mathrm{Na}_{2} \mathrm{SO}_{4}$} \\
\hline & & $7 d$ & $13 \mathrm{~d}$ & $7 d$ & $13 d$ \\
\hline \multirow{6}{*}{$\begin{array}{l}\text { SOD activity (enzyme } \\
\text { activity unit } \cdot \mathrm{g}^{-1} \mathrm{FW} \text { ) }\end{array}$} & $\mathrm{CK}$ & $98.000 \mathrm{c}$ & $85.600 \mathrm{f}$ & $102.289 \mathrm{~d}$ & $90.510 f$ \\
\hline & 0.20 & $98.005 \mathrm{c}$ & $77.600 \mathrm{e}$ & $98.333 \mathrm{c}$ & $79.400 \mathrm{e}$ \\
\hline & 0.40 & $93.543 b$ & $49.800 \mathrm{~d}$ & $97.815 \mathrm{c}$ & $54.800 d$ \\
\hline & 0.60 & $96.067 \mathrm{c}$ & $29.067 \mathrm{c}$ & $96.954 \mathrm{c}$ & $40.867 \mathrm{c}$ \\
\hline & 0.80 & $58.694 a$ & $27.200 \mathrm{~b}$ & $82.823 b$ & $32.600 \mathrm{~b}$ \\
\hline & 1.00 & $58.886 a$ & $17.133 \mathrm{a}$ & $69.354 a$ & $26.867 \mathrm{a}$ \\
\hline \multirow{6}{*}{$\begin{array}{c}\text { POD activity } \\
\left(\mathrm{A} 470 \cdot \mathrm{min}^{-1} \cdot \mathrm{g}^{-1} \mathrm{FW}\right)\end{array}$} & $\mathrm{CK}$ & $14.318 \mathrm{a}$ & $17.955 \mathrm{a}$ & $16.126 \mathrm{a}$ & $18.822 \mathrm{a}$ \\
\hline & 0.20 & $17.647 \mathrm{ab}$ & $28.313 b$ & $17.833 \mathrm{ab}$ & $30.333 b$ \\
\hline & 0.40 & $18.833 \mathrm{bc}$ & $52.133 \mathrm{c}$ & $19.311 b$ & $53.833 \mathrm{c}$ \\
\hline & 0.60 & $15.815 \mathrm{ab}$ & $49.100 \mathrm{c}$ & $20.631 b$ & $56.667 d$ \\
\hline & 0.80 & $21.968 \mathrm{c}$ & $60.256 \mathrm{~d}$ & $27.462 \mathrm{c}$ & $62.000 \mathrm{e}$ \\
\hline & 1.00 & $28.126 \mathrm{~d}$ & $58.293 d$ & $30.314 \mathrm{c}$ & $71.833 \mathrm{f}$ \\
\hline
\end{tabular}

Note: Analysis of variance is at the 0.05 level. $a, b, c \ldots \ldots$ is significant difference between different salt concentrations (in line).It is same in thereinafter. 
Effects of Salt Stress on the Enzyme Activity and Chlorophyll Content of Bush Cinquefoil (Potentilla fruticosa L.)

\subsection{Effect of Salt Stress on Photosynthetic Pigment Content in Leaves of Bush Cinquefoil}

As shown in table 2, with the increase of salt concentration, chlorophyll a, chlorophyll $b$ and total chlorophyll content in leaves of Bush Cinquefoil decreased significantly by. after different salt stress treatments. However, under the same stress intensity, the content of chlorophyll treated with $\mathrm{NaCl}$ was higher than that treated with $\mathrm{Na}_{2} \mathrm{SO}_{4}$, which indicated that chlorophyll synthesis in leaves of Bush Cinquefoil was more destroyed under $\mathrm{Na}_{2} \mathrm{SO}_{4}$ stress, and its light energy capture, transmission and conversion were all affected to a greater extent by.

Under salt stress, the carotenoid content of all salt treatments reached significant difference level, but the change was not significant, floating. above and below CK Under the same stress time and concentration, the content of carotenoids under $\mathrm{NaCl}$ stress was lower than that under the reduced $\mathrm{Na}_{2} \mathrm{SO}_{4}$ stress, which indicated that the content of carotenoids in leaves of Bush Cinquefoil was more sensitive to $\mathrm{NaCl}$ stress in.

The chlorophyll $\mathrm{a} / \mathrm{b}$ value in leaves of Bush Cinquefoil increased first and then decreased with the increase of $\mathrm{NaCl}$ concentration and reached the maximum value of. When the salt concentration was $0.4 \%$ (after 7 days of stress) and $0.6 \%$ (after 13 days of stress) Under $\mathrm{Na}_{2} \mathrm{SO}_{4}$ stress, chlorophyll a/b value showed a decreasing trend first and then increasing trend in. The ratio of total chlorophyll to carotenoids showed a downward trend with the increase of salt concentration, which indicated that the effects of $\mathrm{NaCl}$ and $\mathrm{Na}_{2} \mathrm{SO}_{4}$ stress on the total chlorophyll content were higher than those on the carotenoid content in.

Table2. Effect of salt stress on photosynthetic pigments content of Potentilla fruticosa L. leaves

\begin{tabular}{|c|c|c|c|c|c|}
\hline & \multirow{3}{*}{$\begin{array}{c}\% \\
\text { Salt } \\
\text { Concentration } \\
\end{array}$} & \multicolumn{4}{|c|}{ (d) days of treatment } \\
\hline & & \multicolumn{4}{|c|}{$\mathrm{NaCl} \quad \mathrm{Na}_{2} \mathrm{SO}_{4}$} \\
\hline & & $7 d$ & $13 \mathrm{~d}$ & $7 d$ & $13 \mathrm{~d}$ \\
\hline \multirow{6}{*}{$\begin{array}{c}\left(\mu \mathrm{g} \cdot \mathrm{g}^{-1}\right) \\
\text { Chla content }\end{array}$} & $\mathrm{CK}$ & $22.908 \mathrm{f}$ & $18.636 \mathrm{e}$ & $21.575 \mathrm{e}$ & $18.636 \mathrm{f}$ \\
\hline & 0.20 & $20.877 \mathrm{e}$ & $19.841 \mathrm{f}$ & $15.841 \mathrm{~d}$ & $15.447 \mathrm{e}$ \\
\hline & 0.40 & $20.080 \mathrm{~d}$ & $15.266 \mathrm{c}$ & $15.492 \mathrm{~d}$ & $12.231 \mathrm{~d}$ \\
\hline & 0.60 & $18.151 \mathrm{c}$ & $16.217 \mathrm{~d}$ & $13.308 \mathrm{c}$ & $10.741 \mathrm{c}$ \\
\hline & 0.80 & $14.394 \mathrm{~b}$ & $12.911 \mathrm{~b}$ & $10.877 \mathrm{~b}$ & $10.577 \mathrm{~b}$ \\
\hline & 1.00 & $10.650 \mathrm{a}$ & $7.201 \mathrm{a}$ & $9.820 \mathrm{a}$ & $6.526 a$ \\
\hline \multirow{6}{*}{$\begin{array}{l}\left(\mu \mathrm{g} \cdot \mathrm{g}^{-1}\right) \\
\text { Chlb content }\end{array}$} & CK & $4.595 \mathrm{f}$ & $4.553 \mathrm{e}$ & $4.795 f$ & $4.919 \mathrm{f}$ \\
\hline & 0.20 & $4.174 \mathrm{e}$ & $3.895 \mathrm{~d}$ & $3.770 \mathrm{e}$ & $4.342 \mathrm{e}$ \\
\hline & 0.40 & $3.603 \mathrm{~d}$ & $2.819 \mathrm{c}$ & $3.589 \mathrm{~d}$ & $3.138 \mathrm{~d}$ \\
\hline & 0.60 & $3.315 \mathrm{c}$ & $2.620 \mathrm{~b}$ & $3.012 \mathrm{c}$ & $2.335 \mathrm{c}$ \\
\hline & 0.80 & $2.779 \mathrm{~b}$ & $2.476 \mathrm{~b}$ & $1.958 \mathrm{~b}$ & $1.942 b$ \\
\hline & 1.00 & $2.329 \mathrm{a}$ & $2.047 \mathrm{a}$ & $1.450 \mathrm{a}$ & $0.830 \mathrm{a}$ \\
\hline \multirow{6}{*}{$\begin{array}{c}\left(\mu \mathrm{g} \cdot \mathrm{g}^{-1}\right) \operatorname{Chl}(\mathrm{a}+\mathrm{b}) \\
\text { content }\end{array}$} & $\mathrm{CK}$ & $27.503 \mathrm{f}$ & $23.189 \mathrm{e}$ & $26.370 \mathrm{f}$ & $23.555 f$ \\
\hline & 0.20 & $25.051 \mathrm{e}$ & $23.736 f$ & $19.612 \mathrm{e}$ & $19.789 \mathrm{e}$ \\
\hline & 0.40 & $23.683 d$ & $18.085 \mathrm{c}$ & $19.082 \mathrm{~d}$ & $15.369 d$ \\
\hline & 0.60 & $21.466 \mathrm{c}$ & $18.837 \mathrm{~d}$ & $16.321 \mathrm{c}$ & $13.076 \mathrm{c}$ \\
\hline & 0.80 & $17.173 b$ & $15.387 b$ & $12.836 \mathrm{~b}$ & $12.519 b$ \\
\hline & 1.00 & $12.979 \mathrm{a}$ & $9.248 \mathrm{a}$ & $11.270 \mathrm{a}$ & $7.356 \mathrm{a}$ \\
\hline \multirow{6}{*}{$\begin{array}{c}\left(\mu \mathrm{g} \cdot \mathrm{g}^{-1}\right) \\
\text { Car content }\end{array}$} & $\mathrm{CK}$ & $5.863 \mathrm{f}$ & $6.417 \mathrm{f}$ & $5.863 \mathrm{a}$ & $6.417 \mathrm{e}$ \\
\hline & 0.20 & $4.836 \mathrm{~b}$ & $5.105 \mathrm{e}$ & $6.354 b$ & $6.769 \mathrm{f}$ \\
\hline & 0.40 & $5.216 \mathrm{~d}$ & $4.638 \mathrm{~d}$ & $6.542 \mathrm{~d}$ & $4.420 \mathrm{a}$ \\
\hline & 0.60 & $4.874 \mathrm{c}$ & $4.258 \mathrm{a}$ & $6.629 \mathrm{e}$ & $5.034 b$ \\
\hline & 0.80 & $4.037 \mathrm{a}$ & $4.378 \mathrm{~b}$ & $6.777 \mathrm{f}$ & $5.881 \mathrm{c}$ \\
\hline & 1.00 & $5.267 \mathrm{e}$ & $4.572 \mathrm{c}$ & $6.472 \mathrm{c}$ & $6.106 \mathrm{~d}$ \\
\hline \multirow{6}{*}{ Chl a/b } & CK & $4.985 \mathrm{c}$ & $4.093 \mathrm{e}$ & $4.499 \mathrm{c}$ & $3.789 \mathrm{~d}$ \\
\hline & 0.20 & $5.002 \mathrm{c}$ & $5.094 d$ & $4.202 c$ & $3.558 \mathrm{e}$ \\
\hline & 0.40 & $5.573 a$ & $5.415 b$ & $4.317 \mathrm{c}$ & $3.898 \mathrm{~d}$ \\
\hline & 0.60 & $5.475 \mathrm{ab}$ & $6.190 \mathrm{a}$ & $4.418 \mathrm{c}$ & $4.600 \mathrm{c}$ \\
\hline & 0.80 & $5.180 \mathrm{bc}$ & $5.214 \mathrm{c}$ & $5.555 \mathrm{~b}$ & $5.446 \mathrm{~b}$ \\
\hline & 1.00 & $4.573 \mathrm{~d}$ & $3.518 \mathrm{f}$ & $6.772 \mathrm{a}$ & $7.863 \mathrm{a}$ \\
\hline
\end{tabular}


Effects of Salt Stress on the Enzyme Activity and Chlorophyll Content of Bush Cinquefoil (Potentilla fruticosa L.)

\begin{tabular}{|c|c|c|c|c|c|}
\hline \multirow{5}{*}{ Chl (a+b) /Car } & CK & $4.691 \mathrm{~b}$ & $3.614 \mathrm{~d}$ & $4.498 \mathrm{a}$ & $3.671 \mathrm{a}$ \\
\cline { 2 - 6 } & 0.20 & $5.180 \mathrm{a}$ & $4.650 \mathrm{a}$ & $3.087 \mathrm{~b}$ & $2.923 \mathrm{~b}$ \\
\cline { 2 - 6 } & 0.40 & $4.540 \mathrm{bc}$ & $3.899 \mathrm{c}$ & $2.917 \mathrm{c}$ & $3.053 \mathrm{~b}$ \\
\cline { 2 - 6 } & 0.60 & $4.404 \mathrm{~cd}$ & $4.424 \mathrm{~b}$ & $2.462 \mathrm{~d}$ & $2.223 \mathrm{c}$ \\
\cline { 2 - 6 } & 0.80 & $4.254 \mathrm{~d}$ & $3.515 \mathrm{~d}$ & $1.894 \mathrm{e}$ & $2.832 \mathrm{~b}$ \\
\cline { 2 - 6 } & 1.00 & $2.464 \mathrm{e}$ & $2.023 \mathrm{e}$ & $1.741 \mathrm{f}$ & $1.205 \mathrm{~d}$ \\
\hline
\end{tabular}

\subsection{Correlation Analysis of Chlorophyll Content with Superoxide Dismutase and Peroxidase} Activities in Leaves under Salt Stress

As shown in table 3, after 7 days of $\mathrm{NaCl}$ stress, SOD was significantly negatively correlated with pod, chlorophyll a, chlorophyll $\mathrm{b}$, and chlorophyll total were significantly positively correlated with SOD, chlorophyll b was significantly negatively correlated with pod, and chlorophyll a, chlorophyll total were significantly negatively correlated with pod. After 13 days of $\mathrm{NaCl}$ stress, SOD activity and pod activity reached a very significant negative correlation with; Chlorophyll a and total chlorophyll were significantly and positively correlated with SOD, while chlorophyll b was significantly and positively correlated with SOD in. The correlation between pod and chlorophyll a was not significant, but extremely significant negative correlation with chlorophyll $b$, and significantly negative correlation with total chlorophyll.

Sod and pod reached extremely significant negative correlation. in all stages of $\mathrm{Na}_{2} \mathrm{SO}_{4}$ stress After 7 days of $\mathrm{Na}_{2} \mathrm{SO}_{4}$ stress, chlorophyll a and chlorophyll content were significantly positively correlated with SOD and negatively correlated with pod in; Chlorophyll $b$ was positively correlated with SOD and negatively correlated with pod in. After 13 days of $\mathrm{Na}_{2} \mathrm{SO}_{4}$ stress, chlorophyll a, chlorophyll b, total chlorophyll and SOD were significantly and positively correlated with each other in; Chlorophyll a was negatively correlated with pod, while chlorophyll $b$ and chlorophyll total were negatively correlated with pod in.

Table1. The coefficient of correlation of morphological and physiological characters of Potentilla fruticosa $L$. leaves under salt stress

\begin{tabular}{|c|c|c|c|c|c|c|c|}
\hline & $\begin{array}{c}\text { days of } \\
\text { treatment } / \mathrm{d}\end{array}$ & & $\mathrm{X} 1$ & $\mathrm{X} 2$ & X3 & X4 & X5 \\
\hline \multirow{10}{*}{$\mathrm{NaCl}$} & \multirow{5}{*}{7} & $\mathrm{X} 1$ & 1 & & & & \\
\hline & & $\mathrm{X} 2$ & $-0.880 *$ & 1 & & & \\
\hline & & X3 & $0.916^{*}$ & $-0.924 * *$ & 1 & & \\
\hline & & $\mathrm{X} 4$ & $0.862 *$ & $-0.861 *$ & $0.969 * *$ & 1 & \\
\hline & & $\mathrm{X5}$ & $0.911 *$ & $-0.918 * *$ & $0.999 * *$ & $0.978 * *$ & 1 \\
\hline & \multirow{5}{*}{13} & $\mathrm{X} 1$ & 1 & & & & \\
\hline & & $\mathrm{X} 2$ & $-0.941 * *$ & 1 & & & \\
\hline & & X3 & $0.838^{*}$ & -0.785 & 1 & & \\
\hline & & $\mathrm{X} 4$ & $0.976 * *$ & $-0.976 * *$ & $0.830 *$ & 1 & \\
\hline & & $\mathrm{X5}$ & $0.884 *$ & $-0.839 *$ & $0.995 * *$ & $0.881 *$ & 1 \\
\hline \multirow{10}{*}{$\mathrm{Na}_{2} \mathrm{SO}_{4}$} & \multirow{5}{*}{7} & $\mathrm{X} 1$ & 1 & & & & \\
\hline & & $\mathrm{X} 2$ & $-0.974 * *$ & 1 & & & \\
\hline & & X3 & $0.825 *$ & $-0.895^{*}$ & 1 & & \\
\hline & & $\mathrm{X} 4$ & $0.924 * *$ & $-0.973 * *$ & $0.973 * *$ & 1 & \\
\hline & & $\mathrm{X} 5$ & $0.852 *$ & $-0.917^{*}$ & $0.999 * *$ & $0.984 * *$ & 1 \\
\hline & \multirow{5}{*}{13} & $\mathrm{X} 1$ & 1 & & & & \\
\hline & & $\mathrm{X} 2$ & $-0.986 * *$ & 1 & & & \\
\hline & & $\mathrm{X} 3$ & $0.964 * *$ & $-0.981 *$ & 1 & & \\
\hline & & $\mathrm{X} 4$ & $0.982 * *$ & $-0.976^{* *}$ & $0.985 * *$ & 1 & \\
\hline & & $\mathrm{X} 5$ & $0.971 * *$ & $-0.982^{* *}$ & $0.999 * *$ & $0.992 * *$ & 1 \\
\hline
\end{tabular}

** Correlation is significant at the 0.01 level (2-tailed)

* Correlation is significant at the 0.05 level (2-tailed)

Note: X1 SOD, X2 POD, X3 Chla, X4 Chlb, X5 Chl (a+b)

\section{DISCUSSION}

\subsection{Effect of Salt Stress on Enzyme Activity}

Under adverse circumstances, plants need to rely on the balance of active oxygen metabolism to maintain their normal growth and development of. Salt stress can induce plants to produce a large 
amount of reactive oxygen species, and excessive accumulation of reactive oxygen species will produce oxygen stress on seedlings [6]. Antioxidant enzymes can remove excess active oxygen in plants and reduce the damage of salt stress to seedlings [7,8]. In this experiment, with the increase of salt stress intensity, SOD and pod activities showed a downward trend, and SOD activities were significantly different between different treatment concentrations after 7 days of $\mathrm{NaCl}$ stress, 7 days of $\mathrm{Na}_{2} \mathrm{SO}_{4}$ stress, and 13 days of stress. pod activities were significantly different between different treatments after 13 days of salt stress. Compared with $\mathrm{NaCl}$, the changes of SOD and pod activities under $\mathrm{Na}_{2} \mathrm{SO}_{4}$ stress were smaller than those under $\mathrm{NaCl}$ stress, which indicated that the antioxidant enzyme system of Bush Cinquefoil (Potentilla fruticosa $\mathrm{L}$.) was more sensitive to $\mathrm{NaCl}$ stress in.

\subsection{Effects of Salt Stress on Photosynthetic Pigments}

Pigment is an important substance in plant photosynthesis. its content directly affects the intensity of photosynthesis and is an important indicator of plant salt tolerance. In this study, with the increase of salt concentration, a large amount of $\mathrm{Na}^{+}$and $\mathrm{Cl}^{-}$accumulated in Bush Cinquefoil, resulting in a significant decrease in chlorophyll a, chlorophyll $\mathrm{b}$, and chlorophyll content in. This indicates that the accumulation of $\mathrm{Na}^{+}$and $\mathrm{Cl}^{-}$in the body of Bush Cinquefoil destroys the ion balance in the cell, leading to the relaxation of protein binding between chlorophyll and thylakoid membrane [7] and the enhancement of chlorophyllase activity [8], accelerating the decomposition of. by chlorophyll. When plants grow in saline environment, the contents of $\mathrm{Na}^{+}$and $\mathrm{Cl}^{-}$accumulate in their bodies, which leads to a decline in photosynthesis. this has been confirmed in a large number of literatures. however, for different plants, there is a certain difference in the degree of decline in the dominant ion and photosynthetic rate [9]. In this study, under the same stress intensity, the decrease of chlorophyll content under $\mathrm{NaCl}$ stress was significantly smaller than that under $\mathrm{Na}_{2} \mathrm{SO}_{4}$, which indicated that chlorophyll in leaves of Prunus humilis was more sensitive to $\mathrm{Na}_{2} \mathrm{SO}_{4}$ stress, $\mathrm{Na}^{+}$concentration might be the main ion affecting photosynthesis of Prunus humilis, and. needs to be further verified.

Carotenoids can not only absorb and transmit light energy, but also quench active oxygen to protect [10]. for photosynthesis. Carotenoids in leaves of Bush Cinquefoil did not change much under salt stress, floating up and down in CK. the results were consistent with those of Chen shigang[11]research of salt stress on carotene species of poplar tree. The carotenoid content was higher than $\mathrm{CK}$ after 7 days of $\mathrm{Na}_{2} \mathrm{SO}_{4}$ stress and reached the maximum value at $0.2 \%$ salt concentration after 13 days of stress, and higher than CK. other salt treatment values were lower than $\mathrm{CK}$, suggesting that carotenoids played a protective role under short-term (7 days) of $\mathrm{Na}_{2} \mathrm{SO}_{4}$ and low-salt stress, but under long-term (13days) and high-salt stress, the carotenoid decomposition rate accelerated or synthesis was hindered by. In addition, under the same stress time and concentration, the content of carotenoids under $\mathrm{NaCl}$ stress is lower than that under $\mathrm{Na}_{2} \mathrm{SO}_{4}$ stress, which shows that carotenoids are more sensitive to $\mathrm{NaCl}$ stress. however, under the medium and low salt stress in this study, $\mathrm{Na}_{2} \mathrm{SO}_{4}$ stress is more harmful to chlorophyll production. it can be seen that carotenoids have certain protective effect on chlorophyll, but they do not play a key role in.

Under salt stress, the carotenoid content of all salt treatments reached significant difference level, but the change was not significant, floating. above and below CK Under the same stress time and concentration, the content of carotenoids under $\mathrm{NaCl}$ stress was lower than that under the reduced $\mathrm{Na}_{2} \mathrm{SO}_{4}$ stress, which indicated that the content of carotenoids in leaves of Bush Cinquefoil was more sensitive to $\mathrm{NaCl}$ stress in.

Chlorophyll $\mathrm{a} / \mathrm{b}$ in leaves of Bush Cinquefoil increased first and then decreased with the increase of $\mathrm{NaCl}$ concentration, which indicated that chlorophyll a was higher than chlorophyll $b$ under $\mathrm{NaCl}$ stress and the change trend of chlorophyll $\mathrm{a} / \mathrm{b}$ in leaves of Cinnamomum camphora Seedlings was the same in studies such as Han haozhang[12]; However, the concentration of $\mathrm{Na}_{2} \mathrm{SO}_{4}$ showed an upward trend, which indicated that the degree of damage to chlorophyll b caused by $\mathrm{Na}_{2} \mathrm{SO}_{4}$ stress was greater.

Under $\mathrm{NaCl}$ and $\mathrm{Na}_{2} \mathrm{SO}_{4}$ stress, the total chlorophyll/carotenoid ratio decreased with the increase of salt concentration, which indicated that salt stress had a greater influence on the total chlorophyll content and had a smaller influence on the carotenoid content, which was consistent with the research conclusions of Rao and Han haozhang [12-13]. 


\subsection{Correlation Analysis}

After 7 days of $\mathrm{NaCl}$ stress, SOD was negatively correlated with chlorophyll a, chlorophyll $\mathrm{b}$ and chlorophyll content in; Under $\mathrm{Na}_{2} \mathrm{SO}_{4}$ stress for 7 days, SOD was significantly and positively correlated with chlorophyll a and chlorophyll total, and was significantly and positively correlated with chlorophyll b in; Under $\mathrm{NaCl}$ stress for 13 days, SOD was significantly and positively correlated with chlorophyll a and chlorophyll total, and was significantly and positively correlated with chlorophyll b in; Under $\mathrm{Na}_{2} \mathrm{SO}_{4}$ stress for 13 days, SOD was significantly and positively correlated with chlorophyll a, chlorophyll b, and total chlorophyll content, which indicated that SOD could provide long-term protective effect on chlorophyll under salt stress, especially with chlorophyll $b$, and the protective effect was strongest in.. However, under $\mathrm{NaCl}$ and $\mathrm{Na}_{2} \mathrm{SO}_{4}$ stress, pod was negatively correlated with chlorophyll a, chlorophyll $\mathrm{b}$ and total chlorophyll, which indicated that pod did not play a protective role on chlorophyll.

\section{CONCLUSION}

To sum up, under $\mathrm{NaCl}$ stress, SOD activity, pod activity and carotenoid content are lower than those under $\mathrm{Na}_{2} \mathrm{SO}_{4}$ stress, while chlorophyll content is higher than that under $\mathrm{Na}_{2} \mathrm{SO}_{4}$ stress, which indicates that $\mathrm{NaCl}$ stress has a greater influence on the oxidase system of Prunus humilis, and $\mathrm{Na}_{2} \mathrm{SO}_{4}$ stress has a greater influence on photosynthesis of Prunus humilis. in order to fully analyze the reasons, further research on. is needed in terms of the distribution of salt ions in the body and the influence of salt ions on the microstructure of plants. In addition, this project only analyzed the results of pot seedlings of Bush Cinquefoil under single salt stress, and whether the results of field multi-salt stress experiments can be consistent is still to be further studied in.

\section{ACKNOWLEDGMENT}

The authors are thankful to the Jiangsu Agri-animal Husbandry Vocational College for providing infrastructural facility and financial support (Grant NO: NSF201612).

\section{REFERENCES}

[1] Yan Wenhu, Ji Dianrong, Li Dongyi. The primary colors of wild flowers in China [M]. Northeast Forestry University press, 1999.

[2] Chen Chen, Zhang Xingwang, Luo Zhimin. Determination of quercetin and kaempferol in Potentilla fruticosain different areas by RP-HPLC [J]. Chinese Journal of Analysis Laboratory 2009, 28(12): 54-56.

[3] Zhang Jianfeng, Song Yumin, Xing Shangjun. Saline Soil Amelioration and Forestation Techniques [J]. Journal of Northeast Forestry University, 2002, 30(6): 124-129.

[4] Лочинок X H (Jing Jiahai translation), 1976). Method of Plant Biochemistry Analysis [M]. Beijing: Science Press, 1981.

[5] Zou Qi.Plant Physiology [M]. Beijing: China Agricultural University press, 2000: 163-166.

[6] Parida A K, Das A B. Salt tolerance and salinity effects on plants: A review [J]. Ecotoxicology and Environmental Safety, 2005, 60: 324-349.

[7] You Jia, ZhangJin, Wang Wen-Rui, LuJin, Jia Peng-Xiang, Miao Jian-Shun, Yang Ying-Li. Changes of Physiological Properties in Limonium aureum(Linn.) Hill Seedlings under Salt Stress [J]. Bulletin of Botanical Research, 2013, 33(1): 45-50.

[8] Zhou Hong-bing, Wang Ying-chun, Shi Song-li, Zhou Jian-hua.Response of Antioxidant System in Leaves of Tetraenamongolica and Zygophyllumxanthoxylon Seedlings to Drought Stress [J]. Acta Botanica Boreali-OccidentaliaSinica, 2010, 30(11): 1188-1194.

[9] Zhu Xinguang, Zhang Qide. Progress in the study of the effect of $\mathrm{NaCl}$ on Photosynthesis [J]. Chinese Bulletin of Botany, 1999, 16(4): 332-338.

[10] Willekens H, Vancamp W, Lnze D. Ozone, sulfur dioxide and ozone ultraviolet-B have similar effect on mRNA accumulation of antloxidant genes in Nicotianaplumbaginifolia L. [J]. Plant Physiol, 1994, 106: 1007-1014.

[11] Chen Shigang, Li Qingmei, Tao Jing, Wang Xiancheng, Wang Xiancheng and Zhang Weisheng. Effects of salinization stress on photosynthetic pigment content to several poplar species [J]. Jilin Forestry Science AndTechnology, 2005, 34(6): 8-12. 
[12] Han Haozhang, Wang Xiaoli, Zhang Ying, Liu Yu, Zhang Lihua Zhang Nan. Effect of salt stress on photosynthetic characteristic and antioxidant enzyme system of Cinna-momumcamphora seedlings in autumn [J]. Acta AgriculturaeZhejiangensis, 2014, 26(5): 1235-1239.

[13] Rap G G, Rao G R. Pigment Composition \& Chlorophyllase Activity in Pigment Pea (Cajanus Indicus Spreng) \&Gingelley(SeamunIndicum L.) under NaCl Salinity[J]. Indian J Exp Biol, 1981, 19: 768-770.

Citation: Hang LIU et al., "Effects of Salt Stress on the Enzyme Activity and Chlorophyll Content of Bush Cinquefoil (Potentilla fruticosa L.)", International Journal of Forestry and Horticulture (IJFH), vol. 4, no. 3, pp. 1-7, 2018. http://dx.doi.org/10.20431/2454-9487.0403001

Copyright: () 2018 Authors. This is an open-access article distributed under the terms of the Creative Commons Attribution License, which permits unrestricted use, distribution, and reproduction in any medium, provided the original author and source are credited. 